\title{
Molecular and cytogenetic abnormalities in acute myeloid leukemia: review and case studies
}

\author{
Alterações citogenéticas e moleculares em leucemia mieloide aguda: \\ revisão e descrição de casos

\begin{abstract}
Elvira Deolinda Rodrigues Pereira Velloso ${ }^{1}$, Carlos Henrique Ares Silveira da Motta ${ }^{2}$ Juliana Braga Furtado $^{2}$, Nydia Strachman Bacal ${ }^{3}$, Paulo Augusto Achucarro Silveira ${ }^{1}$, Cynthia Bachir Moyses ${ }^{4}$, Roberta Sitnik ${ }^{4}$, João Renato Rebello Pinho ${ }^{4}$
\end{abstract}

\begin{abstract}
Objective: To study the frequency of mutations that may lead to a good or bad prognosis, as well as their relation with the karyotype and immunophenotype in patients with acute myeloid leukemia. Methods: Thirty samples of patients with acute myeloid leukemia were studied, in which FLT3-ITD, FLT3TKD and NPM1 mutations were investigated. All samples were submitted to immunophenotyping and 25 to karyotyping. Results: An occurrence of $33.3 \%$ NPM1 mutation and an equal number of FLT3-ITD mutation were observed. When only the cases with normal karyotype were studied, this figures increased to 50 and $40 \%$, respectively. Eight percent of cases with normal karyotype and genotype NPM1+/FLT3- were included in the group of acute myeloid leukemia with good prognosis. The typical phenotype of acute myeloid leukemia with normal karyotype and mutated NPM1 (HLA-DR and CD34 negative) was not observed in this small series. Conclusion: Good prognosis cases were identified in this series, emphasizing the need to include new genetic markers in the diagnostic routine for the correct classification of acute myeloid leukemia, to more properly estimate prognosis and determine treatment.
\end{abstract}

Keywords: Leukemia, myeloid, acute/genetics; Cytogenetics; Genetic makers; Chromosome aberrations

\section{RESUMO}

Objetivo: Estudar a frequência de mutações, que podem configurar bom ou mau prognóstico, bem como sua relação com estudo de cariótipo e imunofenotípico, em portadores de leucemias mieloides agudas. Métodos: Foram estudadas 30 amostras de portadores de leucemias mieloides agudas, que foram submetidas à pesquisa das mutações FLT3-ITD, FLT3-TKD e NPM1. Todas as amostras foram submetidas a estudo imunofenotípico e 25 delas foram submetidas a estudo cariotípico. Resultados: Pudemos observar frequência de 33,3\% de mutação NPM1 e igual número em FLT3$I T D$, frequência que se elevou para 50 e $40 \%$ quando se estudaram apenas os casos com cariótipo normal. Dos casos com cariótipo normal, 8\% apresentaram o genótipo NPM1+/FLT3-, migrando para 0 grupo de leucemia mieloide aguda de bom prognóstico. Não observamos o fenótipo típico das leucemias mieloides agudas com cariótipo normal e NPM1 mutado (HLA-DR e CD34 negativos) nesta pequena casuística. Conclusão: 0 presente estudo foi capaz de identificar casos de bom prognóstico, enfatizando que há necessidade de se incorporarem à rotina diagnóstica novos marcadores genéticos, para a correta estratificação prognóstica e orientação terapêutica das leucemia mieloide aguda.

Descritores: Leucemia mieloide aguda/genética; Citogenética; Marcadores genéticos; Aberrações cromossômicas

\section{INTRODUCTION}

Acute myeloid leukemia (AML) is a heterogeneous group of neoplastic diseases with a large variability in regard to the clinical course and response to

\footnotetext{
Study carried out at Special Technical Laboratory (LATE), Hospital Israelita Albert Einstein - HIAE, Sao Paulo (SP), Brazil.

${ }^{1}$ Hematology, Department of Clinical Pathology, Hospital Israelita Albert Einstein - HIAE, São Paulo (SP), Brazil.

${ }^{2}$ Graduate Program in Citogenetics and Molecular Biology, Special Techniques Laboratory (LATE), Hospital Israelita Albert Eisntein - HIAE - São Paulo (SP), Brazil.

${ }^{3}$ Division of Flow Cytometry, Department of Clinical Pathology, Hospital Israelita Albert Einstein - HIAE, São Paulo (SP), Brazil.

${ }^{4}$ Special Technical Laboratory (LATE), Hospital Israelita Albert Eisntein - HIAE - São Paulo (SP), Brazil.

Corresponding author: Elvira Deolinda Rodrigues Pereira Velloso - Laboratório de Técnicas Especiais do Hospital Israelita Albert Einstein - Avenida Albert Einstein, $627 / 701$ - Morumbi - CEP $05651-901$

- São Paulo (SP), Brasil - Tel.: (11) 2151-5555 - Fax: (11) 2151-2122 - e-mail: elviradv@einstein.br

Received: Jan 11, 2011 - Accepted: May 10, 2011
}

Conflict of interest: none 
treatment, as well as in their genetic and molecular basis (more than 300 chromosomal translocations and genetic mutations have been described). More than one mutagenic event is probably necessary to give origin to the disease, encompassing cell proliferation mechanisms (class I mutations, such as $B C R-A B L$, FLT3, RAS, c-Kit, PTPN11, NF1, TEL-PDGRß) and differentiation block (class II mutations, such as $C B F \beta$ MYH11, AML1-ETO, TEL-AML1, PML-RARA, MLL, NUP98-HOXA9, PU.1, C/CEP $\alpha, A M L 1, A M L-A M P 19$, CEBPA, NPM1) $)^{(1,2)}$.

In addition to age, cytogenetic and molecular changes present upon diagnosis are the main variables associated to AML prognosis. Until five years ago, cytogenetic abnormalities defined three risk groups for AML patients younger than 60 years. Approximately $25 \%$ of patients belonged to the low risk group, with $\mathrm{t}(15 ; 17), \mathrm{t}(8 ; 21)$ and inv(16); 25 to $30 \%$ of the unfavorable risk, with the following gene rearrangement: $M L L, \mathrm{t}(6 ; 9), \mathrm{t}(9 ; 22)$, monosomy/ deletions of chromosomes 5 and 7, inv(3)(q21q26) and complex karyotypes. Finally, 50 to $60 \%$ of patients had intermediate risk with $\mathrm{t}(9 ; 11),+8,-\mathrm{Y}$ and normal karyotype, the latter accounting for up to $50 \%$ of the cases ${ }^{(3-5)}$. The estimated five-year survival for those with cytogenetic subtypes for low, intermediate and high risk was 55, 38 and $11 \%$, respectively, in a series of 609 AML patients aged under 60 years ${ }^{(4)}$.

Elderly patients traditionally have a higher percentage of cytogenetic abnormalities related to bad prognosis (up to 51\%) and a lower percentage of good prognosis (about 4\%) $)^{(6)}$. There is a drop in the survival curves of those aged over 60 years for the same cytogenetic subtype, with the exception of acute promyelocytic leukemia (APL), according to a study of 1225 AML patients ${ }^{(5)}$. Farag et al. also demonstrated that for the population older than 60 and treated with classic chemotherapeutic regimens, only $6 \%$ were alive after 5 years ${ }^{(7,8)}$.

In the last few years, many genetic abnormalities were discovered in normal karyotype AML, especially mutations in the NPM1 (nucleophosmin), FLT3 (fmsrelated tyrosine kinase 3); CEPBA (CCAAT/enhancer binding protein $\alpha$ ); $M L L P T D$ (myeloid-lymphoid or mixed-lineage leukemia), NRAS- (neuroblastoma RAS viral oncogen), BAALC (brain and acute leukemia gene), $E R G$ (v-ets erythroblastosis virus E26 oncogene-like) genes, among others ${ }^{(9)}$. Approximately $45 \%$ of AML cases have normal karyotype; in that, the mutations of NPM1 and FLT3 genes are the most prevalent, corresponding to 45 to $55 \%$ and 35 to $45 \%$ of the cases, respectively ${ }^{(10)}$.
FLT3 gene, in chromosome 13q12, encodes a receptor with tyrosine-kinase activity related to the activation of the cell proliferation signaling pathways, which is intensely expressed in the initial phases of myeloid precursor cells. Mutations like FLT3-ITD consist of in-tandem insertions of variable length in the region that encodes the receptor juxtamembrane domain. On the other hand, the FLT3-TKD mutation is punctual and affects the tyrosine-kinase domain. Both result in constant tyrosine-kinase activity. FLT3ITD mutation appears in 35 to $45 \%$ of AML cases with normal karyotype, while the FLT3-TKD mutation is found in less than $5 \%^{(10)}$.

The NPM1 gene, in chromosome 5q35, encodes a nucleolar phosphoprotein that makes the transportation between nucleus and cytoplasm, and is directly involved in the regulation and stability of nuclear proteins. The most frequent mutation is the duplication of four pairs of bases in exon 12 (85\% of cases), but other types of insertion of four pairs of bases can also occur in the same region. This mutation causes the aberrant location of protein NPM1 in cytoplasm ${ }^{(11)}$.

It has been demonstrated that normal karyotype AML with mutation in the NPM1 and CEBPA genes or in both have favorable prognosis, whilst mutations in gene FLT3 bear unfavorable prognosis. The cases with simultaneous mutations in genes FLT3 and NPM1 correlate to intermediate prognosis ${ }^{(12)}$.

Based on such knowledge, the World Health Organization (WHO), in 2008, classified AML into different groups, including AML with recurrent genetic abnormalities that comprise nine subtypes, two of them being temporary entities (Chart 1$)^{(13,14)}$.

Chart 1. Classification of the World Health Organization, 2008, for acute myeloid leukemias.

AML with recurrent genetic abnormalities

AML with t(8;21)(q22;q22)- RUNX1T1-RUNX1

AML with inv(16)(p13.1q22) or t(16;16)(p13.1;q22)- CBFB-MYH11

Acute promyelocitic leukemia with $t(15 ; 17)$ (q22;q21)- PML-RARA

AML with t(9;11)(p22;q23)- MLLT3-MLL

AML with $\mathrm{t}(6 ; 9)(\mathrm{p} 23 ; \mathrm{q} 34)$ - DEK-NUP214

AML with inv(3) (q21; q26.2) or t(3;3) (q21;q26.3) RPN1-EVI1

AML (megakaryoblastic) with $\mathrm{t}(1 ; 22)(\mathrm{p} 13 ; q 13)-$ RBM15-MKL1

AML with NPM1 mutation - temporary entity

AML with CEBPA mutation - temporary entity

AML with alterations related to myelodysplasia

Myeloid neoplasms related to therapy

Non specified AML

Myeloid sarcoma

Myeloid proliferations related to Down syndrome

Blastic plasmacytoid dendritic cell neoplasm

AML: acute myeloid leukemia. 
Therefore, new groups of genetic risk have been recently defined for AML, as depicted in chart 2.

Chart 2. Classification of acute myeloid leukemia, in 2010, per cytogenetic and molecular subtype $\left({ }^{14}\right)$.

\begin{tabular}{|c|c|}
\hline \multirow[t]{5}{*}{ Favorable } & $\mathrm{t}(15 ; 17)(\mathrm{q} 22 ; \mathrm{q} 21)-P M L-R A R A-$ \\
\hline & $\mathrm{t}(8 ; 21)(\mathrm{q} 22 ; \mathrm{q} 22)-R U N X 1 T 1-R U N X 1$ \\
\hline & $\operatorname{inv}(16)(p 13.1 q 22)$ or t(16;16)(p13.1;q22)- CBFß-MYH11 \\
\hline & Mutated NPM1 and with no FLT3-ITD (normal karyotype) \\
\hline & Mutated CEBPA (normal karyotype) \\
\hline \multirow[t]{3}{*}{ Intermediate I } & Mutated NPM1 and with FLT3-ITD (normal karyotype) \\
\hline & Wild-type NPM1 and with FLT3-ITD (normal karyotype) \\
\hline & Wild-type NPM1 and with no FLT3-ITD (normal karyotype) \\
\hline \multirow[t]{2}{*}{ Intermediate II } & $\mathrm{t}(9 ; 11)(\mathrm{p} 22 ; q 23)-$ MLLT3-MLL \\
\hline & Unfavorable or favorable cytogenetic abnormalities \\
\hline \multirow[t]{5}{*}{ Unfavorable } & $\operatorname{inv}(3)(\mathrm{q} 21 ; \mathrm{q} 26.2)$ or $\mathrm{t}(3 ; 3)(\mathrm{q} 21 ; \mathrm{q} 26.3)-R P N 1-E V I 1$ \\
\hline & $\mathrm{t}(6 ; 9)(\mathrm{p} 23 ; \mathrm{q} 34)-$ DEK-NUP214 \\
\hline & $\mathrm{t}(\mathrm{v} ; 11)(\mathrm{v} ; \mathrm{q} 23)-M L L$ rearrangement \\
\hline & $-5 / 5 q-,-7 / 7 q-$ \\
\hline & Complex karyotype \\
\hline
\end{tabular}

Other genetic abnormalities not listed in chart 2 also seem to predict survival. Mutations in $c$-Kit gene seem to be associated to a worse prognosis in AML with $\mathrm{t}(8 ; 21)$ or inv(16), also called CBF-AML (core binding factor $)^{(2,15)}$. Monosomic karyotype, defined as the karyotype with two or more autosomal monosomies or one autosomal monosomy associated to the structural anomaly, has also been associated to the worst risk $\operatorname{group}^{(16,17)}$.

Multiparametric flow cytometry is essential to characterize myeloid neoplasias and analyze a large number of cells in a short period of time, characterizing many antigens per cell. The identification of leukocyte differentiation antigensin the membrane and cytoplasm, allows for the detection of mixed, aberrant phenotypes, and the follow-up of minimal residual disease. The expression of certain antigens, such as CD7, CD11b, CD14, CD56 and CD34 may be associated to adverse prognosis. Aberrant phenotypes are found in at least $75 \%$ of $\mathrm{AML}^{(13)}$. Immunophenotyping demonstrated peculiar features for AML with mutated NPM1, that is, antigen expression of CD13, CD33 and MPO concurrent with the expression of monocytic antigenes CD14 and CD11b, and the absence of the expression of CD34(13).

\section{OBJECTIVE}

To study the rate of mutations that may be associated to a good or bad prognosis, as well as their relation to karyotype and immunophenotype studies in patients with AML.

\section{METHODS}

The Special Technique Laboratory of the Hospital Israelita Albert Einstein (HIAE) receives samples of AML patients from different treatment centers for immunophenotyping, cytogenetic and molecular studies. As from 2009, after signing the informed consent, 30 bone marrow samples from newly diagnosed or relapsed AML patients were submitted to study of FLT3-ITD, FLT3-TKD and NPM1 mutations. All samples were submitted to immunophenotypic study and 25 of them to kariotyping.

The immunophenotyping study was performed using cells labeled with monoclonal antibodies for proliferative panel (CD2, CD4, CD7, CD10, CD11b, CD11c, CD13, CD14, CD15, CD19, CD20, CD22, CD33, CD38, CD34, CD56, CD64, CD71, CD117, HLA-DR, glycophorin A, CD3 c, MPOc, TdT and CD79a). After preparing with ammonium chloride (hemolytic buffer), flow cytometry was performed (Epics XL-MCL or FC-500 - Beckman Coulter).

Cytogenetic study was carried out in 24- and 48hour cultures, with no stimulating agents, submitted to G-banding and described according to the international nomenclature (ISCN 2009).

For analysis of the mutations in FLT3 and NPM1 genes, the DNA of the samples was extracted using the QIAmp DNA Blood Mini Kit (Quiagen), purified (EXOSAP) and submitted to PCR for amplification, using specific primers and labeled for the FLT3ITD (exon 14/15) and NPM1 mutations. Capillary electrophoresis was utilized for analyses of FLT3-ITD and NPM1 per fragment size. To investigate FLT3TKD mutations, a new PCR reaction was performed with specific primers for the Nested-PCR, followed by sequencing. The analysis of the FLT3-ITD and NPM1 mutations were performed by means of the software GeneMapper, and the sequencing, by SeqScape.

\section{RESULTS}

The description of the immunophenotypical, molecular, and karyotypicl findings is depicted on chart 3.

In the cases studied, NPM1 gene mutation was found in 10 out of 30 samples $(33.3 \%)$, the same been observed for the FLT3-ITD mutation. The coexistence of both occurred in six cases. No sample was positive for the FLT3-TKD mutation.

Of the 25 samples with karyotypes analyzed, 10 had normal karyotypes (40\%). When only normal karyotypes were analyzed, $50 \%$ presented the mutation in NPM1 gene and 40\% FLT3-ITD mutation. The concurrent presence of both was diagnosed in $30 \%$ of the cases. 
Molecular and cytogenetic abnormalities in acute myeloid le

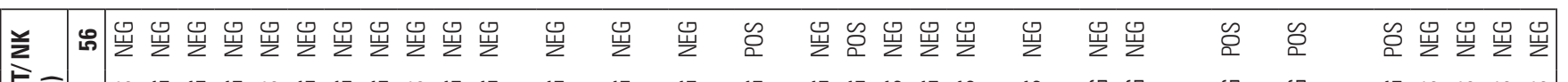

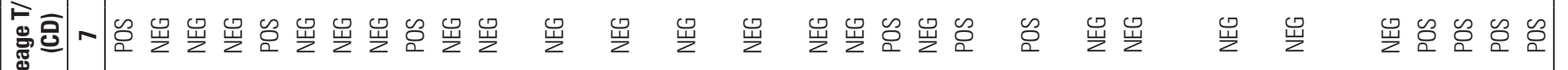

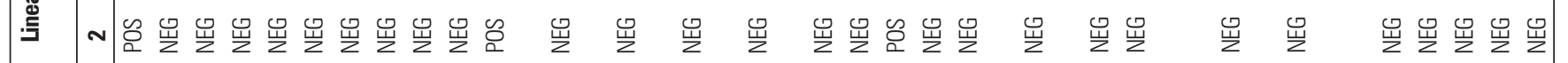

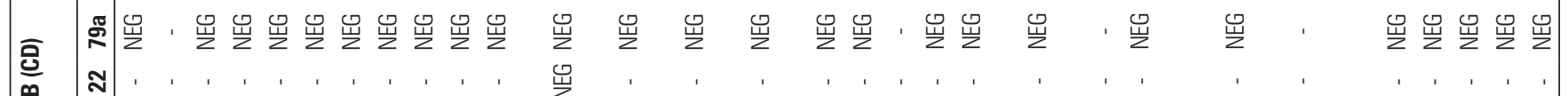

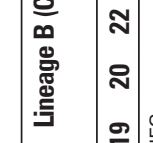

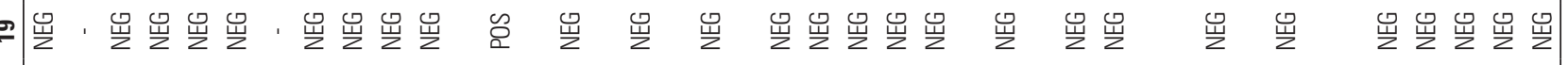

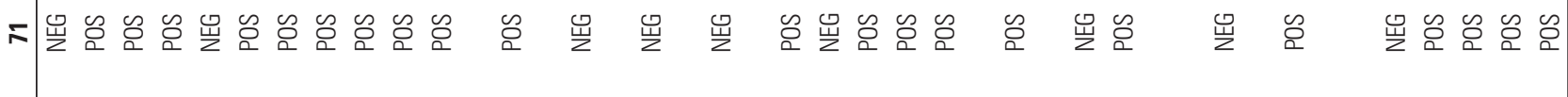

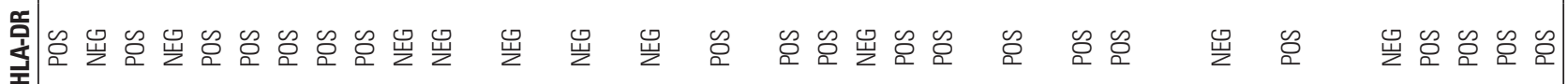

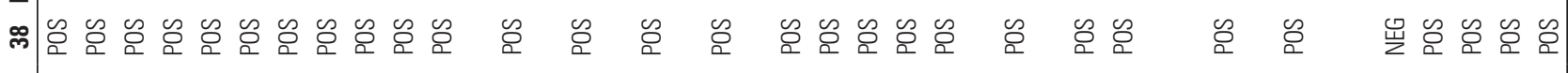

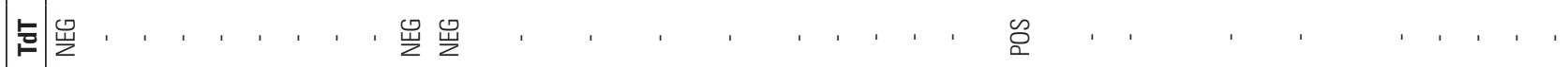

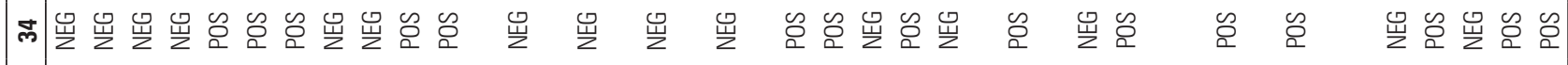

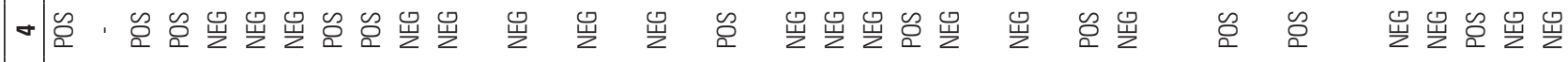

可

衰密

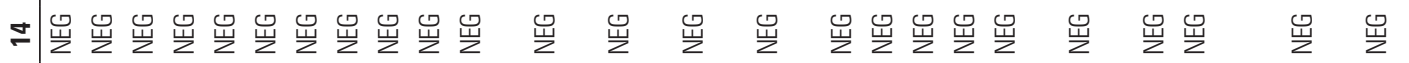

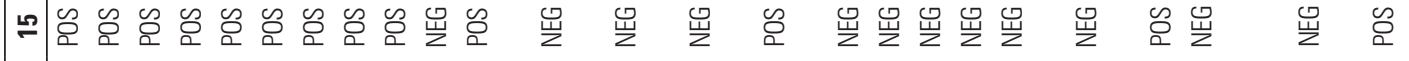

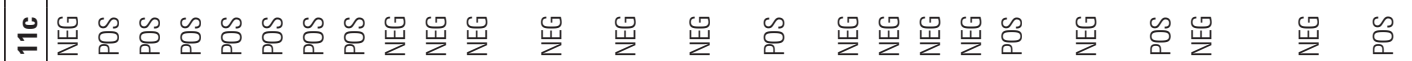

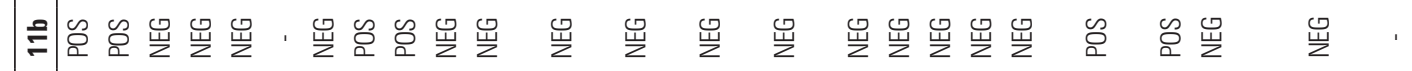

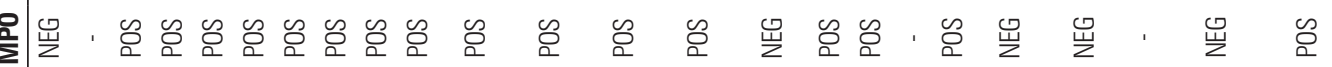

(

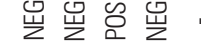

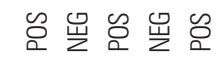

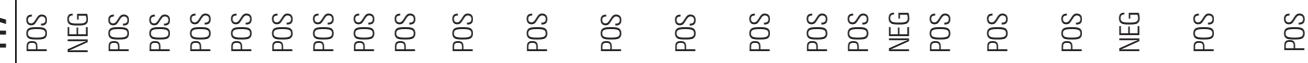

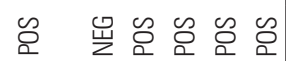

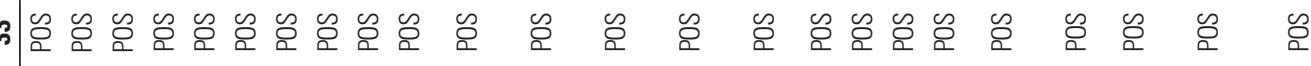

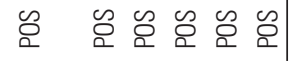

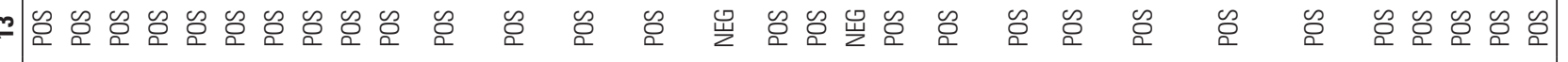

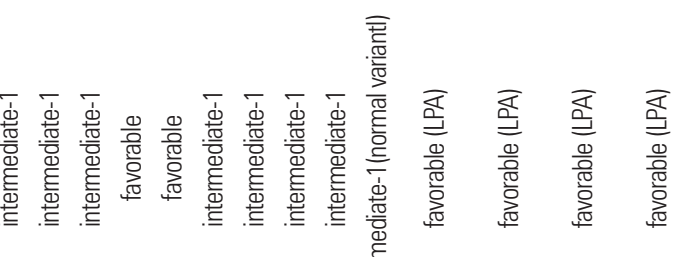
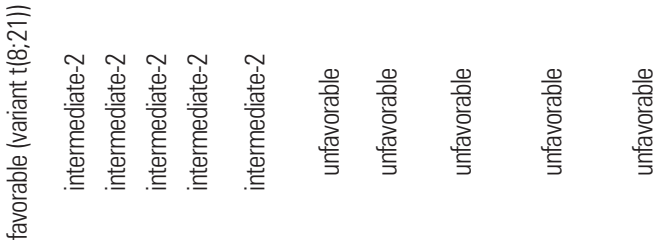

글

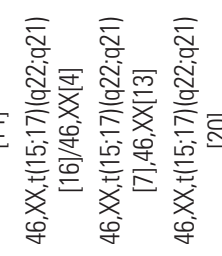

更

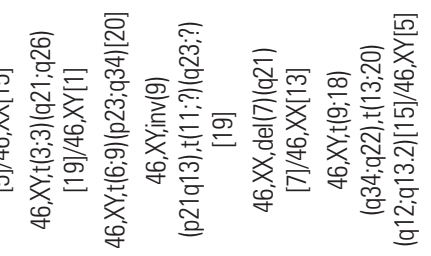

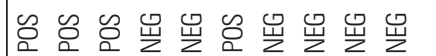

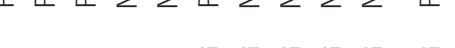

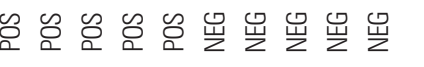

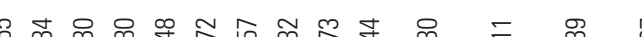

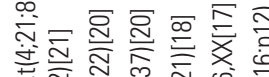

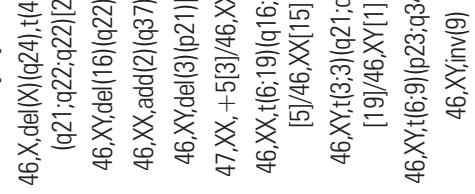

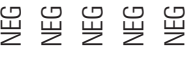

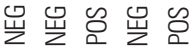

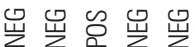

o 00

就

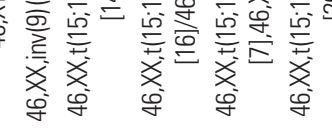

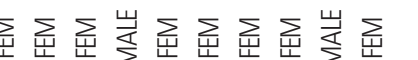

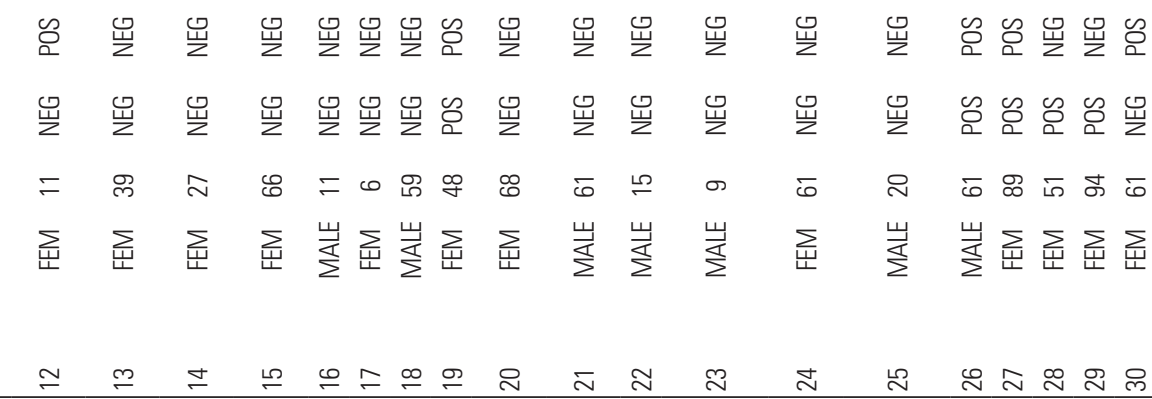


Among the 15 samples diagnosed with abnormal karyotype, 4 presented karyotypes with $t(15 ; 17)$ and one with the variant $t(8 ; 21)$, considered of good prognosis. Five samples presented karyotypes of unfavorable prognosis, $\mathrm{t}(3 ; 3), \mathrm{t}(6 ; 9), \operatorname{del}(7)(\mathrm{q} 21)$, 11 q23 rearrangement and one complex. Five other cases considered of intermediate prognosis such as $\operatorname{del}(16)(\mathrm{q} 22), \operatorname{add}(2)(\mathrm{q} 37), \operatorname{del}(3)(\mathrm{p} 21), 5$ trisomy and $\mathrm{t}(6 ; 19)$ were also found.

Three cases of abnormal karyotypes also presented molecular alterations, two with $\mathrm{t}(15 ; 17)$ and FLT3-ITD mutation, and one 5 trisomy with mutated FLT3-ITD and NPM1.

According to our study, of the 25 cases with karyotype study, $28 \%$ were classified as favorable prognosis, among which $8 \%$ had normal karyotype and mutated NPM1, and $20 \%$ had abnormal karyotype $(16 \% \mathrm{t}(15 ; 17)$, and $4 \% \mathrm{t}(8 ; 21)$. Thirty-two percent were classified as intermediate-1, all with normal karyotype and $12 \%$ mutated NPM1 and FLT3-ITD, $4 \%$ FLT3-ITD and $16 \%$ wild for both mutations. The remaining cases, all with abnormal karyotype, were stratified as intermediate-2 $(20 \%)$ and unfavorable $(20 \%)$ (Figure 1).

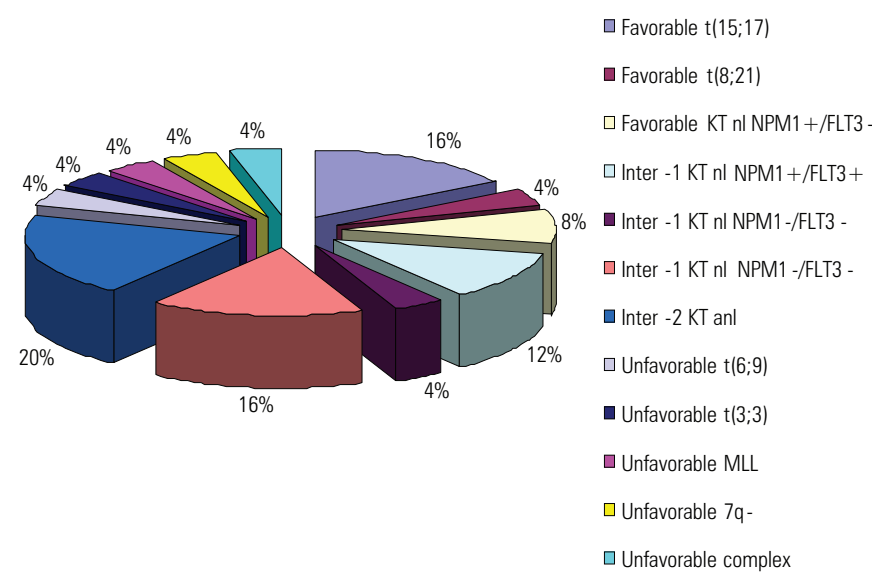

Figure 1. Frequency of prognosis as per the classification of acute myeloid leukemias according to cytogenetic and molecular subtypes .

The immunophenotype study demonstrated that 18 cases $(60 \%)$ expressed non-myeloid lineage-associated antigens: CD7 in 10 cases, CD56 in 5 cases and CD11b in 7 cases; in that, four cases having concurrence of CD7 and CD11b. The expression of CD56 was detected in $16.6 \%$ of AML cases and $20 \%$ of cases with FLT3 mutation.

The immunophenotype study of four cases with wildtype NPM1 and FLT3 mutation ( 2 with normal karyotype and 2 with no karyotype study) demonstrated, in two of them, absence of CD34 expression. Of the 6 cases with mutated NPM1 and FLT3-ITD genotype (3 with normal karyotype, 1 abnormal, 2 with no karyotype study), four had no expression of CD34. Only one of 4 cases of wildtype FLT3-ITD and NPM1 (1 with normal karyotype, 2 with $\mathrm{t}(15 ; 17)$ and 1 with no karyotype study) had absent CD34 expression.

\section{DISCUSSION}

Although a small number of samples from AML patients was studied, the rates observed for FLT3 and NPM1 mutations were similar to those found in the literature, for all subtypes of AML, as well as for AML with normal karyotypes.

In a publication with a national series, a total of $43.7 \%$ in NPM1 mutations were observed in AML subtype with normal karyotype, a rate similar to the one observed in the present study ${ }^{(18)}$. The incidence of $33.3 \%$ FLT3-ITD mutation was slightly higher that reported by LucenaAraujo (23.6\%), being found in the many subtypes of AML, including APL, these data being consonant to the international and national literature ${ }^{(18,19)}$.

Mutation type TKD was not detected, corroborating the less prevalent finding of this mutation in Brazilian series when compared to American or European ones (18-20).

In regard to immunophenotype, the small series hindered comparison with data found in the literature, such as smaller expression of CD56 in the subtype with mutated FLT3 and absence of CD34 expression and HLA-DR in the AML with mutated NPM1. In this study, the rate of expression of CD56 was similar to the one observed in AML with FLT3 mutation and also one of the patients with NPM1+/FLT3- AML presented blast cells with the expression of CD34 and HLA-DR.

Considering the above, it may be inferred that the diagnostic routine should encompass new genetic markers for correct prognostic stratification and treatment option in AML.

\section{CONCLUSION}

The rate of FLT3 and NPM1 mutations found in this series was similar to that found in the literature, and it was possible to identify a subgroup with normal karyotype $N P M 1+/ F L T 3-$, currently recognized as of good prognosis.

\section{ACKNOWLEDGEMENT}

Molecular Biology Technical Team:Diogo P Marquezoni, Gregório TF Tastoli, Juliana NM Rodrigues, Letícia 
Oyakawa, Ozires PS Ramos, Roberta Sitnik, Roberta C Petroni, Rubia AF Santana, Vanessa FD Castro. Cytogenetics Technical Team: Andréa BM Castro, Cláudia IEC Fabris, Cristina A Ratis, Daniel A Oliveira, Daniela Borri, Priscila F Fernandes, Renata C Elias, Renata K Kishimoto, Silvia HA Figueira.

Cytometry Technical Team: Ana Carolina Apelle, Rodolfo P Correia, Ruth H Kanayama, Sonia T Nozawa.

\section{REFERENCES}

1. Reilly JT. Pathogenesis of acute myeloid leukaemia and inv(16)(p13;q22): a paradigm for understanding leukaemogenesis? Br J Haematol. 2005;128(1):1834.

2. Renneville A, Roumier C, Biggio V, Nibourel O, Boissel N, Fenaux P, et al. Cooperating gene mutations in acute myeloid leukemia: a review of the literature. Leukemia. 2008;22(5):915-31.

3. Mrózek K, Bloomfield CD. Chromosome aberrations, gene mutations and expression changes, and prognosis in adult acute myeloid leukemia. Hematology Am Soc Hematol Educ Program. 2006:169-77.

4. Slovak ML, Kopecky KJ, Cassileth PA, Harrington DH, Theil KS, Mohamed A, et al. Karyotypic analysis predicts outcome of preremission and postremission therapy in adult acute myeloid leukemia: a Southwest Oncology Group/Eastern Cooperative Oncology Group Study. Blood. 2000;96(13):4075-83.

5. Schoch C, Kern W, Schnittger S, Büchner T, Hiddemann W, Haferlach T. The influence of age on prognosis of de novo acute myeloid leukemia differs according to cytogenetic subgroups. Haematologica. 2004;89(9):1082-90.

6. Appelbaum FR, Gundacker H, Head DR, Slovak ML, Willman CL, Godwin JE, et al. Age and acute myeloid leukemia. Blood. 2006;107(9):3481-5.

7. Cancer and Leukemia Group B 8461, Farag SS, Archer KJ, Mrózek K, Ruppert AS, Carroll AJ, Vardiman JW, Pettenati MJ, Baer MR, Qumsiyeh MB, Koduru PR, Ning Y, Mayer RJ, Stone RM, Larsson RA, Bloomfield CD. Pretreatment cytogenetics add to other prognostic factors predicting complete remission and long-term outcome in patients 60 years of age or older with acute myeloid leukemia: results from Cancer and Leukemia Group B 8461. Blood. 2006;108(1):63-73.8. Mrózek K, Marcucci G, Paschka P, Whitman SP, Bloomfield CD. Clinical relevance of mutations and gene-expression changes in adult acute myeloid leukemia with normal cytogenetics: are we ready for a prognostically prioritized molecular classification? Blood. 2007;109(2):431-48.

8. Mrózek K, Marcucci G, Paschka P, Whitman SP, Bloomfield CD. Clinical relevance of mutations and gene-expression changes in adult acute myeloid leukemia with normal cytogenetics: are we ready for a prognostically prioritized molecular classification? Blood. 2007;109(2):431-48.
9. Gulley ML, Shea TC, Fedoriw Y. Genetic tests to evaluate prognosis and predict therapeutic response in acute myeloid leukemia. J Mol Diagn. 2010;12(1):3-16.

10. Bacher U, Schnittger S, Haferlach T. Molecular genetics in acute myeloid leukemia. Curr Opin Oncol. 2010;22(6):646-55.Review.

11. Falini B, Bolli N, Liso A, Martelli MP, Mannucci R, Pileri S, et al. Altered nucleophosmin transport in acute myeloid leukaemia with mutated NPM1: molecular basis and clinical implications. Leukemia. 2009;23(10):1731-43.

12. Schlenk RF, Döhner K, Krauter J, Fröhling S, Corbacioglu A, Bullinger L, Habdank M, Späth D, Morgan M, Benner A, Schlegelberger B, Heil G, Ganser A, Döhner $\mathrm{H}$; German-Austrian Acute Myeloid Leukemia Study Group. Mutations and treatment outcome in cytogenetically normal acute myeloid leukemia. N Engl J Med. 2008;358(18):1909-18.

13. Vardiman JW, Bruning RD, Arber DA, Le Beau MM, Porwit A, Tefferi A, et al. Introduction and overview of the classification of the myeloid neoplasms. In: Swerdlow SH, Campo E, Harris NL, Jaffe ES, Pileri SA, Stein H, et al. WHO classification of tumours of haematopoietic and lymphoid tissues. 4th ed. Lyon: IARC, 2008. p. 18-30.

14. Döhner H, Estey EH, Amadori S, Appelbaum FR, Büchner T, Burnett AK, Dombret $H$, Fenaux P, Grimwade D, Larson RA, Lo-Coco F, Naoe T, Niederwieser D, Ossenkoppele GJ, Sanz MA, Sierra J, Tallman MS, Löwenberg B, Bloomfield CD; European LeukemiaNet. Diagnosis and management of acute myeloid leukemia in adults: recommendations from an international expert panel, on behalf of the European LeukemiaNet. Blood. 2010;115(3):453-74.

15. Paschka P, Marcucci G, Ruppert AS, Mrózek K, Chen H, Kittles RA, Vukosavljevic T, Perrotti D, Vardiman JW, Carroll AJ, Kolitz JE, Larson RA, Bloomfield CD; Cancer and Leukemia Group B. Adverse prognostic significance of KIT mutations in adult acute myeloid leukemia with inv(16) and t(8;21): a Cancer and Leukemia Group B Study. J Clin Oncol. 2006;24(24):3904-11.

16. Breems DA, Van Putten WL, De Greef GE, Van Zelderen-Bhola SL, GerssenSchoorl KB, Mellink CH, et al. Monosomal karyotype in acute myeloid leukemia: a better indicator of poor prognosis than a complex karyotype. J Clin Oncol. 2008;26(29):4791-7.

17. Foran JM. New prognostic markers in acute myeloid leukemia: Perspective from the Clinic. Hematology Am Soc Hematol Educ Program. 2010;2010:47-55.

18. Lucena-Araujo AR, Souza DL, Morato de Oliveira F, Benicio MT, Figueiredo-Pontes $\mathrm{LL}$, Santana-Lemos BA, et al Results of FLT3 mutation screening and correlations with immunophenotyping in 169 Brazilian patients with acute myeloid leukemia. Ann Hematol. 2010;89(2):225-8.

19. Emerenciano M, Menezes J, Vasquez ML, Zalcberg I, Thuler LC, Pombo-deOliveira MS; Brazilian Collaborative Study Group of Infant Acute Leukemia. Clinical relevance of FLT3 gene abnormalities in Brazilian patients with infant leukemia. Leuk Lymphoma. 2008;49(12):2291-7.

20. De Lourdes Chauffaille M, Borri D, Proto-Siqueira R, Moreira ES, Alberto FL. Acute promyelocytic leukemia with $t(15 ; 17)$ : frequency of additional clonal chromosome abnormalities and FLT3 mutations. Leuk Lymphoma. 2008:49(12):2387-9. 